Auno: Influência dos polimorfismos dos alelos Mu (GSTM1)

CASSIO Cardoso Filho

ORIENTADOR:

Profa. Dra. Maria Salete Costa Gurgel

Resumo de tese e Theta (GSTT1) do sistema da Glutationa S-transferase na susceptibilidade ao câncer de mama esporádico

\author{
Influence of polymorphisms of the Mu (GSTM1) and Theta (GSTT1) alleles
} of the glutathione $S$-transferase system on the susceptibility to sporadic breast cancer

Palavras-chave

Câncer de mama Polimorfismos genéticos Glutationa S-transferase

Dissertação de Mestrado apresentada ao Departamento de Tocoginecologia da Faculdade de Ciências Médicas da Universidade Estadual de Campinas (UNICAMP) em 13 de julho de 2007.

INTRODUÇÃO: as deleções homozigóticas dos genes GSTMI e GSTTl têm sido associadas ao aumento do risco de várias neoplasias, porém não há consenso de suas influências sobre o câncer de mama. OBJETIVO: avaliar a ocorrência das referidas deleções em mulheres com câncer de mama esporádico (casos) - CME, e em mulheres sem câncer (controles), além de avaliar a associação com características clínicas e biológicas dos casos. Métodos: Foram avaliados 177 casos e 169 controles, com determinação das freqüências das deleções pelo PCR. Estas foram correlacionadas às características clínicas e biológicas através do cálculo de odds ratio com seus respectivos intervalos de confiança de 95\%. RESULTADOS: Observou-se freqüência menor da deleção do GSTM1 em mulheres pardas ( $p=0,1128)$, $O R=0,48(0,24-0,98)$. O risco foi menor de ocorrência de tumores grau nuclear 3 em pacientes com deleção do GSTT 1 $(p=0,04), O R=0,37(0,15-0,90)$. A deleção homozigótica de pelo menos um dos genes associou-se com mulheres que não amamentaram $(p=0,0202), O R=0,41(0,19-0,88)$, e com a ausência de expressão dos receptores hormonais $(p=0,0300), O \operatorname{Radj}=2,25(1,03-4,90)$. Já a deleção de ambos os genes associou-se ao aumento de risco da ocorrência de tipos histológicos diferentes do carcinoma ductal invasivo clássico ( $p=0,0571$ ), ORadj = 12,09 (1,03-142,03). CONCLUSÕES: mulheres pardas com CME tiveram menor freqüência da deleção do GSTM1, enquanto tumores com menor grau de diferenciação nuclear relacionaram-se à deleção do GSTT 1. Já a deleção de um dos genes associou-se a maior risco de tumores que não expressam receptores hormonais, e a deleção combinada de ambos os genes associouse ao aumento de risco para tipo histológico não ductal clássico.

ALUNO:

RÉGis Resende PAULINELLI

ORIENTADOR:

Prof. Dr. RufFO de Freitas-JúNIOR

Resumo de tese

\title{
Modelo de predição de malignidade em nódulos sólidos da mama, baseado na ultra-sonografia
}

\author{
Predictive model for the risk of malignancy in solid breast nodules based \\ on the ultra-sonography
}

Tese de Doutorado apresentada em 26 de outubro de 2007 ao Convênio Centro-Oeste (UnB, UFG, UFMS) para obtenção do Título de Doutor em Ciências da Saúde. Câncer de mama

Diagnóstico

Ultra-sonografia

Key words

Breast

Breast cancer

Diagnosis

Ultrasound

OBJETIVO: criar um modelo preditivo para o risco de malignidade em nódulos sólidos da mama, com expressão ecográfica. MÉTODOS: foram obtidos a aprovação no Comitê de Ética Médica e o consentimento informado. Este estudo multicêntrico prospectivo incluiu prospectivamente 1.403 nódulos sólidos da mama. Cada característica ultra-sonográfica foi analisada e comparada com o diagnóstico definitivo. Os resultados da ultra-sonografia, a idade das pacientes e o histórico familiar de câncer de mama foram incluídos no modelo de regressão logística multivariada. P<0,05. RESULTADOS: dentre as 1.403 lesões incluídas no estudo, $1.390(99,1 \%)$ tiveram um diagnóstico definitivo. Dentre estas, havia $343(24,7 \%)$ tumores malignos e $1.047(75,3 \%$ ) nódulos benignos. As odds ratios (e intervalos de confiança) de malignidade para cada variável incluída no modelo, de acordo com a análise multivariada, foram as seguintes: forma irregular/margem não circunscrita, 16,0 (7,7-33,0); ecotextura heterogênea, 4,5 (2,4-8,2); orientação vertical (não paralela à pele), 2,2 (1,0-4,7); halo ecogênico anterior, 2,6 (1, 1-6,3); sombra posterior, 2,3 (1,2-4,6); idade maior que 40 anos, 2, 1 (1,2-3, 8); histórico familiar de primeiro grau (mãe, irmã, filha), 7,5 (2,6-21, 1). Não houve vantagem em incluir a presença da vascularização interna e de espessamento nos ligamentos de Cooper no modelo. O modelo preditivo foi denominado SONOBREAST e está acessível gratuitamente para uso médico na página da internet: http:// www.sonobreast.com. CONCLUSÃO: a probabilidade de malignidade em tumores mamários pode ser estipulada com base nas suas características ultra-sonográficas, na idade das mulheres e no histórico familiar de câncer de mama. 